Folia Histórica del Nordeste, $\mathbf{N}^{\circ} 19$ (Resistencia, 2011) IIGHI, IH - CONICET, UNNE

\title{
CREATIVIDAD, ADAPTACIÓN Y RESISTENCIA. YCHOALAY, UN CACIQUE ABIPÓN EN LA FRONTERA AUSTRAL DEL CHACO (SIGLO XVIII)
}

\author{
Creativity, Adaptation and Resistance. Ychoalay, a Cacique Abipón in the Southern \\ Border of Chaco (18th Century)
}

\section{Carina Paula Lucaioli}

\section{Resumen}

Las reducciones jesuíticas fundadas para los grupos abipones en el Chaco austral (entre 1748 y 1763) fueron enclaves fronterizos que generaron numerosas y nuevas formas de interacción. Portales entre un mundo colonial y un espacio indígena, sitios biológica y culturalmente mestizos, estos espacios propiciaron la circulación y el intercambio de bienes, personas e ideas, generando nuevas posibilidades sociales, económicas y políticas que los abipones, y especialmente sus líderes, supieron amoldar en función de sus propios intereses. En este trabajo proponemos abordar dicho proceso a partir de la reconstrucción y análisis de la trayectoria particular de un cacique abipón, Ychoalay, personaje clave en la fundación, desarrollo y mantenimiento del pueblo de San Jerónimo de abipones. Como veremos, este cacique supo adaptarse de manera flexible a las diferentes coyunturas históricas y gestar vínculos estratégicos que le permitieran interactuar tanto con sus seguidores indígenas como con distintos funcionarios civiles y religiosos de la sociedad colonial. A través de su trayectoria, Ychoalay nos permitió delinear un compleja coyuntura colonial del siglo XVIII y observar la capacidad indígena de elegir entre el abanico de posibilidades, manipulando lo establecido mediante un proceso dinámico de adaptación y transformación que, en el desarrollo de la interacción, halló los caminos para el mantenimiento de la autonomía indígena.

$$
<\text { Liderazgo indígena }><\text { Reducciones }><\text { Chaco }><\text { Siglo XVIII }>
$$

\begin{abstract}
Between 1748 and 1763 Jesuit reductions were settled in southern Chaco for the Abipones, soon becoming border enclaves with a strong interaction. These spaces in-between the colonial and indigenous worlds generated an intense biological and cultural miscegenation which led to the circulation of goods, people and ideas. In other words, new social, political and economic opportunities challenged the Abipones, and especially their leaders took advantage of them. This paper studies the above-mentioned process based on the reconstruction and analysis of cacique Ycholay's life trajectory since he played a key role in the foundation and development of San Jerónimo, a town of Abipones. He was flexible enough and knew how to adapt to the changing historical circumstances, he also developed strategic links with his indigenous followers and several colonial authorities. His life trajectory enabled us to visualize the complex 18th
\end{abstract}


century colonial context and the indigenous capacity to choose among a range of possibilities, manipulating the established rules through a dynamic process of adaptation and transformation in order to maintain the indigenous autonomy

$<$ Iindigenous leadership $><$ Reductions $><$ Chaco $><18$ th century $>$

\section{Introducción}

Las reducciones jesuitas creadas en el Chaco generaron interesantes puntos de encuentro y negociación entre los grupos indígenas y el sector colonial, de manera que, lejos de tratarse de políticas estatales unidireccionales, sentaron las coordenadas a partir de las cuales los grupos abipones ${ }^{1}$-entre otros- pudieron generar una serie de estrategias y adaptaciones originales para hacer frente al proyecto colonizador ${ }^{2}$. Este proceso creativo y dinámico desplegado por parte de los grupos humanos en contacto, caracterizó las relaciones interétnicas entabladas durante el siglo XVIII generando interesantes procesos de mestizaje y etonogénesis (Boccara 2005). Por lo tanto, consideramos que la interacción colonial no debe interpretarse como la relación entre dos bloques esencialmente dicotómicos, comúnmente caracterizados en la rígida oposición blanco/indio sino como complejos de relaciones que involucraron numerosos sujetos -tanto indígenas como hispanocriollos- en un espacio de negociación que ofrecía nuevas y numerosas posibilidades de acción.

La perspectiva de análisis aquí abordada busca, a través del estudio de los documentos, delinear una trayectoria indígena que restituya el proceso histórico y le devuelva protagonismo a los propios actores. Centrando la mirada en un nivel micro, nos proponemos dar cuenta de las singularidades de los procesos de interacción colonial y de las transformaciones y adaptaciones operadas a mediados del siglo XVIII. Esperamos que, mediante esta estrategia de poner como punto de partida la identificación y exégesis de acontecimientos concretos e históricamente situados, podamos identificar ciertas transformaciones en torno al liderazgo de los grupos abipones. Para ello, proponemos abordar la trayectoria de un conocido cacique -Ychoalay o José Benavides- que, a nuestro entender, permite analizar en detalle tanto

\footnotetext{
${ }^{1}$ Durante el siglo XVIII, los abipones eran grupos nómades, cazadores-recolectores que habitaban en la región austral del Gran Chaco. La organización sociopolítica de los grupos guaycurúes -entre ellos los abipones (Susnik 1971)- se basaba en reconocibles lazos de parentesco y alianzas matrimoniales por medio de las cuales se conformaban pequeños grupos familiares, flexibles en cuanto al agrupamiento de sus miembros y en función del nomadismo, que comúnmente coincidían con grupos políticos no centralizados. Cada individuo fundamentaba su decisión de unirse a las filas de determinado líder en función de sus relaciones de parentesco, ajustándose la dinámica política al ritmo de fusiones y fisiones sociales (Braunstein 1983 y 2008).

${ }^{2}$ Específicamente para los grupos indígenas abipones se fundaron cuatro reducciones en diferentes espacios fronterizos: San Jerónimo, en la jurisdicción de Santa Fe en 1748, Concepción en Santiago del Estero en 1749, San Fernando en la jurisdicción de Corrientes en 1750 y, poco antes de la expulsión de la Orden a Europa, en 1763 se fundó un último pueblo, del Santo Rosario o Timbó, en las inmediaciones de Asunción.
} 
las nuevas posibilidades que brindaron a los abipones los contextos de reducción como las múltiples estrategias que estos caciques pudieron desempeñar en torno a ellas para fortalecer su prestigio y mantener la autoridad.

Asimismo, nuestro enfoque busca tomar distancia de ciertos presupuestos que frecuentemente han teñido los estudios de los contactos coloniales, para los cuales la incorporación de elementos ajenos a la cultura indígena habría sido casi instantánea y producto de la "fascinación" generada por la evidente "superioridad tecnológica" (Boccara 2002). Los nuevos bienes habrían devenido rápidamente en necesarios fomentando una relación de dependencia unilateral de la sociedad aborigen para con los productores/distribuidores de los mismos (Vitar 2003). En ocasiones, estas incorporaciones han sido analizadas en función de rasgos culturales previamente reconocidos, que fortalecían una imagen estática y sincrónica de la sociedad indígena, a partir de la cual los cambios eran interpretados como "pérdida de la cultura" y "abandono de las relaciones tradicionales", lo que habría derivado, tarde o temprano, en procesos de "desestructuración" o "desintegración social" (Susnik 1981) o en la emergencia de "jefaturas intervenidas" fundadas en una mayor dependencia política y económica de la sociedad indígena respecto del respaldo de las autoridades y bienes coloniales (Vitar 2003). Aquí, partimos de que las reducciones fueron un tipo particular de "enclave fronterizo" -espacio colonial situado en territorio indígena con miras defensivas (Nacuzzi 2009)-, contextos propicios de mestizaje y "aculturación antagónica"3 apropiados y resignificados por los grupos indígenas. Por ello, proponemos situar la mirada en la capacidad de adaptación y resistencia de los pueblos indígenas, en la posible emergencia de nuevos patrones de organización (Helms 1969) o de reestructuraciones sociopolíticas y económicas originales y exitosas (Boccara 2002).

\section{Ychoalay: un ir y venir entre mundos mezclados}

Durante la segunda mitad del siglo XVIII, Ychoalay fue el cacique abipón más reconocido por el sector hispanocriollo, tanto por su capacidad de liderazgo frente a los grupos indígenas como por su diplomacia frente a las relaciones fronterizas con el sector colonial. Sin embargo, como veremos, la celebridad de su nombre se habría logrado lentamente con el correr de los años y gracias a sus acciones políticas estratégicas. Los datos más antiguos que hemos obtenido sobre Ychoalay se remontan a las primeras décadas del siglo XVIII. Para aquel momento, este personaje indígena aún no gozaba del renombre y prestigio que luego tendría -tanto entre los suyos como en el ámbito colonial- durante la segunda mitad del siglo. La información, escasa y poco específica, señala que habría entablado tempranamente relaciones laborales en la ciudad de Santa Fe, donde "trabajó para los españoles ya como domador de caballos o como guardián de los campos" (Dobrizhoffer [1784] 1969: 135). Ychoalay no había

\footnotetext{
${ }^{3}$ Concebimos el concepto de "aculturación antagónica" tal como lo propone Bechis (2006) -quien a su vez lo retoma de (Zapater,1985: 58)- como la asimilación creativa y conciente de ciertos rasgos de la vida material y no material de una cultura ajena con el objeto funcional de resistir mejor su dominio.
} 
nacido en cuna noble y si bien en los documentos se le atribuye cierto parentesco con algunos reconocidos caciques abipones ${ }^{4}$, no hemos hallado indicios de que su prestigio y autoridad se basaran en vínculos hereditarios o por sucesión directa de un cargo preexistente. Ychoalay ejercía un determinado tipo de liderazgo en donde la autoridad se nutría del carisma y el prestigio individual del candidato ${ }^{5}$ (Nesis y Lucaioli 2006). Ychoalay era un höcheri ${ }^{6}$; nacido sin status habría escalado en las jerarquías políticosociales gracias a su carisma, su promoción personal y el reconocimiento público de su prestigio guerrero.

Según cuenta Dobrizhoffer ([1784] 1969), uno de los motivos que impulsó a Ychoalay a trabajar para los españoles fue su deseo de aprender la lengua española, idioma que supo dominar y que más tarde le abriría una nueva gama de posibilidades y contactos en tanto vocero y comunicador entre los abipones y el sector hispanocriollo. Aquella inquietud lo habría llevado hasta Chile como cochero de un español que administraba el transporte de carros y, más tarde, habría trabajado como cultivador de sus viñedos en Mendoza. Este mismo autor le atribuye el haberse desempeñado como soldado al servicio de los españoles. De manera que, hasta el momento, comienza a delinearse la imagen de un individuo desenvuelto que estableció un estrecho contacto con la sociedad colonial. Además de haber adquirido el idioma español, Ychoalay forjó experiencia laboral como peón de campo, domador de caballos, cochero, cultivador y soldado, tareas que -cabe suponer- habrían estado acompañadas de valiosos aprendizajes y del dominio de técnicas y tecnologías ajenas a su cultura, como el manejo de armas españolas o los rudimentos de la agricultura. En este sujeto que traspasó las fronteras políticas y culturales, lo indígena y lo hispanocriollo comenzaron a combinarse. Ychoalay fue, desde entonces, un ser culturalmente mestizo.

$\mathrm{Su}$ identidad misma quedó involucrada en este proceso cuando su nombre, su carta de presentación, se vio modificada por los patrones españoles. Ychoalay, de ahí en más, fue identificado por el sector colonial como José Benavides. Dobrizhoffer ([1784] 1969: 135) sostiene que "tomó el nombre de su amo, José Benavides", haciendo referencia a aquel primer español para el cual habría trabajado en las inmediaciones de Santa Fe. Por su parte, Charlevoix ([1779] 1916) narra un episodio de la década de 1730, en el cual un grupo de abipones visitó el Colegio Jesuita. El padre Muriel,

\footnotetext{
${ }^{4}$ Se le atribuye haber sido sobrino de los líderes Niripuri -del cual no hemos encontrado ninguna referencia en los documentos- (Bustillo citado por Furlong 1938: 98) y Quebachín (Klain 11/11/1758). Dobrizhoffer ([1784] 1968: 421) sostiene que era "pariente por la sangre" de Debayakaikin, también llamado el Petiso, célebre por su férrea oposición al proyecto de las reducciones (Lucaioli 2010). El padre Paucke también menciona este parentesco con el Petiso, aunque produce cierta confusión al sostener que su nombre era Alaykin -otro reconocido líder abipón- y no Debayakaikin (Paucke 1944: 304).

${ }^{5}$ El carisma y el prestigio individual han sido considerados dos de los principales atributos que debía reunir un individuo que se dispusiera a ejercer la autoridad entre los grupos indígenas chaqueños (Braunstein 2008). Recientemente hemos sugerido que si bien el carisma era una condición inherente al ejercicio del cargo político habría habido otras formas de autoridad (Lucaioli 2010).

${ }^{6}$ Los höcheris, según Dobrizhoffer ([1784] 1969), eran individuos que por sus méritos militares pasaban a formar parte de una categoría selecta de hombres prestigiosos, jerarquía que se simbolizaba por el uso de un lenguaje particular y por la adquisición de un nombre terminado con la sílaba $i n$.
} 
encargado de corregir la obra de Charlevoix, amplía en pie de página que "prendáronse principalmente los abipones con los beneficios que les hizo el Padre Jesuita Benavides, del cual tomó nombre de Benavides su cacique Ichoalay, y lo llevó ya mucho tiempo antes de bautizarse" (Charlevoix [1779] 1916: 138).

A pesar de contar con distintas versiones acerca del origen de su nuevo nombre español, hay unanimidad en que no se trató de un nombre otorgado, como a otros indígenas, a través del bautismo cristiano. Ychoalay, como lo relata Dobrizhoffer ([1784] 1969), fue durante muchos años reacio a la doctrina y a la religión y, aunque años más tarde en San Jerónimo se volviera un fiel devoto y compañero del cura misionero, no aceptó el bautismo hasta poco antes de la expulsión de los jesuitas.

Hemos presentado a Ychoalay -o Benavides- como un trabajador que supo moverse en el ámbito hispanocriollo desempeñando diferentes tareas y que, incluso, ofició como soldado al servicio colonial. Pero esta es sólo una primera etapa en la historia de este sujeto que "algunos años después volvió de Mendoza a Santa Fe porque su patrón chileno comenzó a no cumplir con la paga estipulada. Y nació en él el disgusto por los españoles" (Dobrizhoffer [1784] 1969: 135). Ychoalay, con la misma aparente facilidad con la que trascendió las fronteras de su mundo indígena para entrometerse en los resquicios coloniales, regresó con los suyos llevando consigo el dominio del idioma, un nuevo nombre, conocimientos y aptitudes y, sobre todo, mucha experiencia. También había forjado un renovado rencor contra los españoles que rápidamente se tradujo en una seguidilla de acciones violentas basadas en la organización de malones y saqueos contra los poblados hispanocriollos. En esta empresa,

Como tuviera la más dura animosidad contra los españoles, se unió a sus compatriotas en cualquier robo y dirigió sus empresas con éxito. De modo que poco después pasó de compañero a jefe [...]. Fue príncipe de todas las victorias y peligros y parte principal de las matanzas (Dobrizhoffer [1784] 1969: 136).

Ychoalay no tardó en reunir bajo sus filas un gran número de seguidores que, ávidos de venganza y de botín, lo secundaron en sus ataques. Así, adquirió la fama de guerrero implacable que lo acompañó el resto de su vida, cimentando las bases para el reconocimiento de su creciente autoridad. A través de estas acciones violentas contra el colonizador se granjeó el respeto de sus seguidores que lo erigieron como líder y organizador:

Repitiendo las expediciones con el mismo éxito, nació aquella celebridad de su nombre, y tanto como fue seguido por los suyos fue temido por los extraños. Por esto, gran cantidad de abipones confiaban en él. El único deseo de todos era vivir con él [...]. Todos veían que con este jefe irían no al combate, sino a la victoria, y que volverían con óptimo botín 
(Dobrizhoffer [1784] 1969: 136).

Estas citas remarcan las características básicas que tradicionalmente debía poseer un líder abipón para erigirse en el cargo: carisma, destreza guerrera y capacidad organizativa y logística para la consecución de grandes botines. Sin embargo, Ychoalay había alimentado con su experiencia otros atributos que no tardaría en desplegar para el fortalecimiento de su autoridad. Como sostiene Nacuzzi (1998: 185), tras la interacción fronteriza aparecieron "nuevas condiciones que serían precisas para acceder a la jefatura: haber viajado mucho, tener amplias relaciones políticas y vinculaciones sociales, conocer el español, ser culturalmente mestizo". Esta frase pensada para los grupos indígenas de la Pampa y la Patagonia no podría ajustarse mejor a los liderazgos que aquí estamos analizando.

Santa Fe fue la primera ciudad colonial en establecer la paz con ciertos grupos abipones entre los cuales muy probablemente se encontraba Ychoalay. Las relaciones de amistad entre abipones y santafesinos trajeron aparejada cierta calma sobre esta frontera, aunque implicó el desplazamiento de las incursiones sobre las ciudades vecinas, situación que preocupó notablemente a los funcionarios civiles y eclesiásticos (Cervera 1907). También Ychoalay supo coordinar sus ansias de victoria bélica y botines sustanciosos con aquella amistad que los abipones habían sellado con Santa Fe, orientando sus empresas guerreras sobre las jurisdicciones vecinas. Por ejemplo, hacia mediados del siglo XVIII, la ciudad de Córdoba señalaba que

Habían penetrado hasta allí los abipones que mandaba el cacique denominado Benavides, y renovaban todos los horrores que tan a menudo habían padecido todas las otras comarcas de aquellas provincias. Hasta se animó Benavides en 1746 a asaltar un convoy de carretas que iba de Buenos Aires al frente de solo 18 indios [...]. Otro convoy salido de Córdoba para Santa Fe, fue sorprendido por una tropa de aquellos mismos indios muy cerca de Río Tercero, siendo muertos 24 españoles y robado el convoy (Charlevoix [1779] 1916: 151).

Sin embargo, desde su regreso a los campamentos abipones, Ychoalay nunca volvió a enfrentarse directamente con Santa Fe (Saeger 2000), manteniendo en equilibrio las relaciones con aquella ciudad en donde había generado buenos amigos y contactos económicos y diplomáticos. Sólo unos años más tarde, en octubre de 1748, Ychoalay estuvo liderando las negociaciones para el emplazamiento de la reducción de San Jerónimo, desempeñando un activo rol de mediación en los acuerdos entre indígenas e hispanocriollos.

Todas las aptitudes que, como hemos señalado, nutrieron su capacidad de liderazgo, adquirieron renovada fuerza y visibilidad cuando hacia mediados del siglo XVIII, Ychoalay optó el establecimiento de una nueva alianza con el sectorhispanocriollo, 
esta vez respaldada por los caminos de la diplomacia y el establecimiento de acuerdos mutuos. Esta nueva tregua con el mundo colonial propició el acercamiento, pero no ya en los viejos términos como trabajador o soldado al servicio de los hispanocriollos, sino como líder, vocero y representante de un determinado grupo de abipones "amigos" a la colonia. En esa coyuntura, algunos caciques abipones y varios agentes del sector colonial -agentes del gobierno y funcionarios eclesiásticos- se encontraron por primera vez, cara a cara, en la mesa de las negociaciones político-diplomáticas dispuestos a establecer los derechos y obligaciones adquiridas por cada una de las partes para garantizar la convivencia pacífica. La cita tuvo lugar en el fortín de Añapiré, espacio fronterizo ubicado en el Pago de Ascochingas al norte de Santa Fe, entre el Arroyo Saladillo y la Laguna de Paiva (Cervera 1969). A este encuentro -denominado "La Paz de Añapiré" (Muriel 1919, Furlong 1938, Cervera 1969)- acudieron también los caciques abipones "nombrados Neruguiyi, Alayquin, Quebachin, Quebachichi, y Ychoalay, con sesenta indios y sus familias" (Actas del Cabildo de Santa Fe 8/6/1748). Ignoramos los detalles de lo parlamentado en estos diálogos, aunque sabemos que estos cinco caciques "convencidos y resignados a obediencia pidieron a su Merced y Padres de la Compañía de Jesús que les instruyesen los misterios de nuestra Santa Fe católica ofreciendo sujetarse a pueblo y doctrina" (Actas del Cabildo de Santa Fe 8/6/1748).

Con el acuerdo de fundación de la primera reducción jesuita creada para los grupos abipones nos adentramos en un nuevo contexto histórico de las relaciones interétnicas fronterizas, el del período jesuítico que para este grupo étnico en particular, se extiende desde 1748 hasta 1767, año en que se resuelve la expulsión de los religiosos de la Compañía de Jesús ${ }^{7}$. A mediados del siglo XVIII tuvo lugar una serie de fundaciones que dio como resultado la creación de cuatro pueblos de abipones en las jurisdicciones de Santa Fe (San Jerónimo, 1748), Santiago del Estero (Concepción, 1749), Corrientes (San Fernando, 1750) y Asunción (del Santo Rosario o Timbó, 1763). Todas ellas fueron enclaves estratégicos y originales en donde confluyeron múltiples relaciones entre el sector indígena y colonial y es por ello que emergen como interesantes espacios de análisis además de que, afortunadamente, fueron ampliamente documentados. En las páginas siguientes enmarcaremos mayormente el análisis en la reducción de San Jerónimo, la más antigua de todas, dado que fue el sitio de refugio y vivienda de Ychoalay desde la fundación del pueblo hasta la muerte del cacique.

\section{Decisiones estratégicas: nuevas alianzas y reorientación de la guerra}

Entre los abipones, como para muchos otros grupos indígenas, la guerra era una institución clave para el desarrollo y la reproducción económica, política y simbólica de la sociedad y, en consecuencia, sus líderes debían ser, ante todo, buenos guerreros (Clastres 1971, Susnik 1981, Saeger 2000, Nesis y Lucaioli 2006). Ya hemos

\footnotetext{
${ }^{7}$ Luego de la expulsión de los jesuitas, las reducciones del Chaco pasaron a manos de misioneros franciscanos. Esto produjo grandes transformaciones en las dinámicas misionales seguidas, principalmente, por una fuerte oleada de despoblamiento y abandono de la mayoría de los pueblos (Saeger 2000).
} 
mencionado que la carrera política de Ychoalay comenzó a partir de sus hazañas y demostraciones de valentía que había sabido forjar como cabeza de los enfrentamientos contra la sociedad hispanocriolla. Durante ese período, que antecedió a la fundación de las reducciones, Ychoalay utilizó inteligentemente las vías tradicionales de acceso al liderazgo -presteza guerrera, calidad ejecutiva y organizativa, capacidad de convocatoria, adquisición de grandes botines, etc.- para posicionarse tanto en un plano de identificación con el sector indígena como de oposición y resistencia al avance colonial. Sin embargo, esta guerra contra los hispanocriollos fue perdiendo vigencia a medida que se hicieron más evidentes las nuevas posibilidades políticas y económicas que prometía una "nueva amistad" con los vecinos de las ciudades coloniales. Hacia mediados del siglo XVIII, las condiciones fronterizas se habían vuelto algo más exigentes para los grupos que se alimentaban con el botín de los robos y los malones en pueblos y estancias. Las reformas borbónicas habían señalado la necesidad de un mayor control sobre las decisiones de los Cabildos y, en consecuencia, impulsaron la implementación de políticas centralizadas. Esta medida limitaba la estrategia interétnica de establecer paces entre determinadas ciudades y ciertos caciques indígenas para beneficiarse del comercio mutuo en detrimento de las jurisdicciones vecinas. Asimismo, los ganados de las estancias se hallaban mejor custodiados o habían sido trasladados a sitios más protegidos, lo que dificultaba doblemente las incursiones indígenas (Djenderedjian 2004). Los grupos abipones que robaban acá para vender allá, estaban presenciando un notable estrechamiento en sus márgenes de acción y las viejas estrategias se mostraban desgastadas y frágiles frente a estos cambios.

A pesar de que los primeros acuerdos para la fundación de San Jerónimo se establecieron con el "cacique principal nombrado Nereguiyi" (Actas del Cabildo de Santa Fe 8/11/1748), Ychoalay, que estuvo presente en la negociación, no tardaría en emerger -al menos para los ojos de los españoles- como cabeza del pueblo de San Jerónimo, ya fuera por sus cualidades personales, o porque Nerugini (Ychamenraikin) habría encausado su prestigio por otros canales menos orientados a la interacción colonial". Tal como lo narra Dobrizhoffer ([1784] 1969: 139) "los progresos en la misión, deben atribuirse, con la ayuda de Dios, a las industrias y a la autoridad de Ychoalay".

Lo cierto es que en el ámbito de las relaciones políticas y diplomáticas con la sociedad colonial, Ychoalay -José Benavides para este sector- pronto fue referencia obligada, cara visible de la reducción y puente entre el sector colonial y la sociedad indígena. Hasta tal punto se habría expandido su renombre entre el sector hispanocriollo que, en los documentos, a pesar de que en San Jerónimo residían muchos otros caciques con sus familias, quedaron invisibilizados bajo fórmulas como: "San Jerónimo de

\footnotetext{
${ }^{8}$ Se trata de una deformación de Nerugini, nombre con el que también se conocía a Ychamenraikin, "cacique principal" de San Jerónimo por nobleza de cuna.

${ }^{9}$ En otro trabajo hemos sugerido la posible coexistencia de dos formas de liderazgo abipón a partir del análisis comparativo de las figuras de los caciques Neruigini (Ychamenraikin), Naaré y Debayakaikin -todos ellos nobles de cuna- y los höcheri o nobles por mérito personal, como Ychoalay (Lucaioli 2010).
} 
indios abipones cuyo habitadores son el indio Joseph Benavides y sus parciales" (Urízar 30/06/1754), "la primera reducción es la del cacique Joseph Benavides" (Castro 16/10/1766) o "El pueblo de Benavides" (Churraca 23/12/1774).

Una de las actuaciones más destacadas de Ychoalay, haciendo uso de su rol de mediador entre la sociedad colonial e indígena, tuvo lugar poco después de la fundación del pueblo, cuando catorce líderes abipones con sus seguidores se reunieron en asamblea en San Jerónimo para debatir conjuntamente los términos en que debían interpretarse y ajustarse las paces interétnicas ${ }^{10}$. Mientras la mayoría de los presentes sostenía que las paces debían acotarse a la ciudad de Santa Fe para preservar como frente de guerra a las otras ciudades fronterizas donde podrían ejercitarse en las artes bélicas -simbólica y políticamente fundamentales para la reproducción de la sociedad-; Ychoalay señalaba que mayores ventajas se lograrían mediante el establecimiento de una paz generalizada que abarcara a las tres provincias chaqueñas: Tucumán, Paraguay y Buenos Aires. Ychoalay alegaba que el prestigio militar se podía alimentar a través de actividades de caza mayor y, en última instancia, con el ejercicio de la guerra orientada a los grupos indígenas enemigos de antaño (Dobrizhoffer [1784] 1969). El arte de la oratoria le sentaba bien a este sujeto que, contra todos los pronósticos, logró persuadir a la mayoría de los abipones presentes y convencerlos de que se firmara una paz general con los distintos frentes coloniales. El acuerdo implicaba que cada uno de los principales caciques participantes se haría responsable de la defensa de una ciudad colonial (Santiago del Estero, Santa Fe, Córdoba, Corrientes y Asunción) y velaría por la paz en sus fronteras (Dobrizhoffer [1784] 1969).

Las paces iniciadas entre los grupos abipones y la sociedad colonial no serían todo lo duraderas que se esperaba, ya que pocos meses después el cacique Oaherkaikin atacó el territorio de Asunción. Este episodio fue, para Ychoalay, la trompeta de guerra que dio inicio a un interminable encadenamiento de sucesos armados entre él y los caciques ofensores de la colonia; guerra que se prolongaría por más veinte años y cavaría una brecha insalvable entre los abipones "amigos de los españoles" y los demás "indios enemigos de los españoles", sean o no abipones ${ }^{11}$. Cabe aclarar que esta división no siempre coincidió con la separación entre "reducidos" y "no reducidos", ya que estos pueblos fueron espacios flexibles y manipulados por los abipones que albergaron esporádicamente tanto a unos como a otros ${ }^{12}$ (Lucaioli 2010).

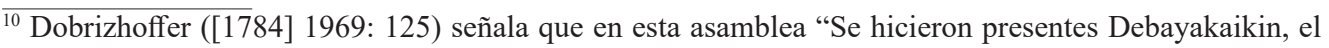
jefe de todos, Kaapetraikin, Kebachin, Alaykin, Malakin, Ypirikin, Oaaikin, Oaherkaikin, todos abipones nakaiketergehes; y Naaré y Kachirikin, abipones yaaukanigás", junto a los caciques que habitaban en el pueblo de San Jerónimo, Ychamenraikin, Ychoalay, Lichinrain y Kebachichi.

${ }^{11}$ Si bien esta división es una constante en cada uno de los enfrentamientos entre abipones, los sujetos eran libres de pasar a uno u otro bando según sus propias inclinaciones o las ventajas que prometiera cada encuentro, con la misma facilidad con la que abandonaban a un líder para seguir a otro. A pesar de esta flexibilidad, Ychoalay por un lado, Debayakakin y Oaherkakin por otro, se mantuvieron firmes en sus decisiones volviéndose los representantes visibles y de cada una de estas posturas antagónicas.

${ }^{12}$ Las reducciones muchas veces funcionaron como sitios seguros de resguardo y defensa para ciertos grupos de abipones que apelaban a las paces cuando la situación al interior del Chaco se volvía insostenible, ya por las encarnizadas luchas con los abipones de San Jerónimo, ya por la falta de recursos y alimentos
} 
La reducción de San Jerónimo, situada a 70 leguas de la ciudad de Santa $\mathrm{Fe}$, emergió como sitio estratégico de contacto y comunicación, bisagra entre "dos mundos", umbrales entre un territorio desconocido para los hispanocriollos ocupado por los grupos indígenas y los terrenos donde se erigían las ciudades y haciendas coloniales. Es aquí, en los márgenes simbólicos y sociales, donde la figura de Ychoalay se vuelve analíticamente significativa y nos permite observar los usos y adaptaciones del mestizaje dado el potencial cultural que poseía tanto como miembro de los abipones y como individuo que supo cosechar estrechas relaciones con la sociedad colonial. En San Jerónimo, Ychoalay se posicionó como mediador entre los intereses coloniales y los de sus seguidores oponiéndose claramente al sector indígena disidente. La reorientación "hacia adentro" de los conflictos bélicos lo impulsó a diseñar el establecimiento de nuevas alianzas ventajosas y en este accionar, poco a poco, fue transformando las bases de su propia autoridad.

Las promesas de ayuda defensiva eran una de las tantas cláusulas que, implícita o tácitamente, acompañaban los acuerdos diplomáticos y las nuevas relaciones de "amistad" (Nacuzzi y Lucaioli 2008). Como hemos señalado, Ychoalay, se mantuvo firme a las paces acordadas con los hispanocriollos "y veló diligentemente que ninguno de sus abipones la violara, aún con el peligro de su cabeza. Supo que algunos habían violado la paz y consideró que debía usar la fuerza y las armas contra ellos como si fueran enemigos (Dobrizhoffer [1784] 1969: 138). Sin embargo, esta actitud que a simple vista puede confundirse como "subordinación" hacia los representantes gubernamentales u obediencia a ciegas de un compromiso, adquiere nuevos matices cuando se la interpreta desde la lógica de una trayectoria indígena particular y no como inscripta en o al servicio de la causa de la colonización. Todo indicaría que Ychoalay no se enfrentaba a los enemigos coloniales en cuanto tales, sino que por sus propias decisiones habría delineado un nuevo frente de combate y, en esta lucha, no estaba solo. La guerra planteada en términos de "abipones contra abipones" -en un principio- se vuelve un interesante contexto de interacción que involucra directa e indirectamente a otros actores sociales tanto indígenas como hispanocriollos.

Tradicionalmente, los grupos indígenas del Chaco acostumbraban a trazar alianzas entre ellos para hacer frente a las hostilidades con otros grupos (Susnik 1981). Estas alianzas -que se traducían en la mutua ayuda defensiva-, solían ser de carácter flexible y laxo y no necesariamente implicaban relaciones de larga duración, de manera que el cuadro de relaciones interétnicas estaba en continua reconfiguración (Saeger 2000). Ychoalay supo adaptar inteligentemente esta estrategia a las nuevas posibilidades y recursos que le brindaba el entorno reduccional. De esta manera, encontramos en numerosas ocasiones a los abipones de San Jerónimo secundados por los mocovíes de San Javier -y ocasionalmente por los abipones de Concepción-, con

que podían ser saldados en los pueblos a través de las entregas de los jesuitas. De esta manera, la solicitud esporádica de paz y albergue en las reducciones se volvió una estrategia efectiva para los caciques "libres" que alternaban sus incursiones en el espacio chaqueño con la vida circunstancial en estos contextos protegidos por la colonia (Lucaioli 2010). 
quienes compartían, esencialmente, el mantenimiento de las relaciones de amistad con el sector colonial:

Mañana sale Joseph [Benavides desde San Jerónimo] con toda la gente y con los mocobis de San Javier para acabar con el Petiso ${ }^{13}[\ldots]$, más como otra vez oigo que Neruguini y Alaiquin [desde Concepción] quieren acompañar la armada no sé en qué parará esta empresa (Brigniel 22/1/1752).

Las ayudas militares prestadas por los mocovíes de San Javier a los abipones de San Jerónimo fueron muchas. El padre Paucke (1764) nos ha dejado un interesante documento en donde enumera las salidas de sus indios en ayuda de los abipones de San Jerónimo y/o para el castigo de los abipones "enemigos". Según este documento, al menos en veintiún ocasiones los mocovíes de San Javier se habrían puesto en armas en defensa de los abipones reducidos en San Jerónimo. No obstante, como hemos mencionado anteriormente, no todos los indígenas reducidos eran potenciales aliados. Un claro ejemplo de esto es que si bien San Jerónimo gozó algunas veces del apoyo de los abipones de Concepción, con motivo de unos robos cometidos en Santiago del Estero por la gente del cacique abipón Alaykin -que residía en Concepción- comenzaron a resquebrajarse los lazos entre ambos pueblos (Sánchez 16/1/1751). Tampoco la reducción de San Fernando fue una aliada de San Jerónimo, la tensión entre ambas reducciones se remonta a la fundación misma de San Fernando cuando el cacique Naré aceptó amparar a Debayakaikin en su pueblo, el principal enemigo de Ychoalay. Los grupos radicados en San Fernando abrazaron la causa guerrera de Oaherkaikin y Debayakaikin sin necesidad de abandonar la misión, utilizando este espacio como lugar de reunión y sitio de resguardo. Aquí se evidencia, nuevamente, el entramado de posibilidades que se entretejía en el espacio de la reducción, permitiendo a los grupos indígenas un ir y venir interesado sin mayores compromisos de lealtad para con la sociedad colonial. El uso que hicieran los indígenas de estos espacios estratégicos propició que el enfrentamiento entre abipones muchas veces tuviera lugar en el escenario reduccional: "llegó a San Fernando una india que venía de San Jerónimo y dijo a Naare que Benavides decía que acabada la sementera vendría de guerra contra San Fernando" (Patrón 8/9/1758).

Ychoalay, como se puede apreciar con estas citas, exigía de la amistad mucho más de lo que esperaban los propios hispanocriollos. Para ellos, la intención de reducirse brindaba ya cierta sujeción -más simbólica que real- sobre aquellos indios, por lo tanto, siempre fueron bienvenidas las propuestas de los caciques hostiles de sumarse a los pueblos. Debayakaikin, por ejemplo, habitó tanto en Concepción como en San Fernando. Incluso, fueron sus seguidores los que, años después de su muerte, solicitaron en el Paraguay la reducción del Timbó y lograron conseguirla a pesar de las enormes dificultades que encontraron los asunceños para mantenerla (Susnik 1971).

\footnotetext{
${ }^{13}$ Petiso era el nombre con que el se conocía al cacique Debayakaikin en el sector colonial, uno de los principales abipones hostiles a las paces y enemigo acérrimo de Ychoalay.
} 
La actitud de Ychoalay, por el contrario, se había vuelto más exigente. Es aquí, en este desfasaje en donde se hace más explícito que sus motivaciones no coincidían exactamente con las de los hispanocriollos. Ychoalay no era un funcionario indígena con órdenes coloniales, este caudillo no buscaba colaborar con la colonización como un fin en sí mismo, sino que había encontrado en la coyuntura fronteriza un intersticio por donde encauzar sus propias ambiciones de liderazgo y contar, para ello, con el apoyo y la alianza de los funcionarios coloniales. En su carrera política, Ychoalay tensó al máximo la flexibilidad de las instituciones indígenas, moviéndose en un campo liminal entre las prerrogativas de la autoridad y las tentaciones del poder. Al reconstruir la historia de vida de este cacique a través de los documentos, hemos hallado en varias ocasiones indicios de ciertas atribuciones que se separan de lo que el ejercicio de la autoridad tradicional le hubiera permitido. Sólo para citar un ejemplo de este tipo de actitudes, señalamos que cuando se estaba tramitando la fundación de Concepción, mientras el cacique Alaykin acompañado de Ychamenraikin se hallaban en Santiago del Estero acordando una mutua entrega de cautivos, Ychoalay se quedó en San Jerónimo con la tarea de recolectar a todos los cautivos españoles que vivieran dispersos entre los distintos campamentos abipones situados en el interior del Chaco (Breve relación s/f). Entre los abipones, los cautivos eran propiedad de quien los había tomado y sus muchas funciones en el entramado de las relaciones interétnicas los volvían piezas valiosas para el grupo que los poseía (Lucaioli 2010). Por lo tanto, la tarea de Ychoalay de "rescatar" los cautivos españoles en manos de otros grupos de abipones quebraba la norma tradicional de las competencias de un cacique sobre otro. Esta jugada estratégica de Ychoalay habría sido captada por el cura de San Jerónimo, quien explicitó en estas pocas líneas aquel espacio ambiguo y complejo en el que se estaba moviendo este sujeto:

el capitán Ychoalai dice, que luego irá por todos los toldos a juntarlos [a los cautivos], y que los pondrá a todos a vista de los padres que estamos aquí, si lo ejecuta gran cosa hará, porque hallaría bastantes oposiciones, más si quisiese valor, y autoridad tiene para salir en ello (Brigniel 6/4/1749).

No queremos dejar de señalar que estas nuevas funciones que Ychoalay se arrogaba -aunque con excusas de defender las paces con la colonia- no necesariamente estaban en concordancia con lo que el sector hispanocriollo esperaba. Es decir, las consecuencias de sus acciones muchas veces repercutían de manera negativa en las fronteras, reactivando los enfrentamientos. En cierta ocasión, el Teniente de Gobernador de Corrientes Nicolás Patrón le escribe al Gobernador de Buenos Aires José de Andonaegui anunciando las tensiones y mutuos recelos entre los distintos caciques abipones surgidas luego de que Ychoalay quebrara los códigos tradicionales. Con notable indignación por las repercusiones de sus acciones -marcando nuevamente que sobrepasaban el límite tolerado-, Patrón escribía que Ychoalay 
intentó levantarse con el dominio de los demás de su nación, se extendió tanto el crédito del indio entre los santafesinos que aún a mí me persuadieron a lo mismo, hasta que el tiempo, y los acaecimientos del expresado Benavides, me lo han manifestado, hasta que de estos desordenados procedimientos, se han seguido tan fatales consecuencias, como el estar al presente casi todos los caciques del valle en guerra contra dicho Benavides y los que han sido de su facción, y esto con tanta ardentía que si prosigue adelante, el pueblo de San Jerónimo, que es donde Benavides, no tendrá estabilidad (Patrón 24/3/1750, el destacado es nuestro).

Los enfrentamientos entre abipones no pueden explicarse únicamente por la guerra en la frontera y responden a rivalidades previas a esta coyuntura. Sin embargo, Ychoalay logró reinscribir aquellas hostilidades en el discurso colonial y gozar de la alianza con algunos sectores hispanocriollos en esta empresa. Durante el tiempo que duró la guerra entre los abipones, Ychoalay contó con el apoyo no sólo de los "mocovíes cristianos" y algunos otros caciques abipones, sino que también logró convocar en algunas ocasiones a las fuerzas de milicias coloniales (Actas del Cabildo de Santa Fe 10/6/1754, Dobrizhoffer [1784] 1969), haciendo valer los derechos adquiridos por "las dichas paces, que han motivado que en dos ocasiones hubiese salido este vecindario a auxiliar a dicho Benavides, y su pueblo nombrado San Jerónimo contra la persecución de dichos infieles" abipones no reducidos (Actas del Cabildo de Santa Fe 21/11/1775). Sin embargo, la mayoría de las veces la ayuda colonial se hizo desear y a pesar de que Ychoalay moviera personalmente sus contactos viajando hasta Santa Fe para entrevistarse con el Teniente de Gobernador Antonio de Vera Mujica y recordara la contraprestación adeudada, la ayuda se demoraba tanto como fuera posible (Dobrizhoffer [1784] 1969: 152). Lo cierto es que, en cuestiones defensivas, el frente colonizador pudo gozar con mayor asiduidad del apoyo de San Jerónimo mientras estaba a cargo de los jesuitas y más aún, durante la etapa de incursiones al Chaco que precedió la firma de tratados con los grupos mocovíes y tobas en la década de 1770:

sabe y le consta que el cacique Joseph Benavides se halla en la dicha jurisdicción de Santa Fe, en la reducción que se cita, muy sujeto y subordinado a los españoles, de tal modo que cuando hacen entradas a tierras de enemigos, los auxilian y ayudan aún contra sus mismos paisanos, como también dicho cacique da indios da escoltas a los pasajeros que transitan con tropas de mulas y carretas [...] y siempre que el Teniente de Santa Fe le ordena a dicho cacique que de la escolta, lo hace inmediatamente (Castro 3/12/1766).

Si en cuestiones de guerra, Ychoalay sólo ocasionalmente logró contar con el apoyo hispanocriollo y las luchas con otros indígenas se volvieron más encarnizadas 
y conflictivas, nos preguntamos qué fue lo que motivó a este líder a pagar un precio tan alto por una lealtad no correspondida. $Y$ es en este punto donde debemos volver la mirada, nuevamente, sobre la perspectiva individual, en un nivel más acotado que el que proponen las amplias coordenadas del conflicto colonial. Nos inclinamos a pensar que Ychoalay, en estas acciones, no necesitaba del apoyo de las tropas hispanocriollas, ya que era de esperar que un verdadero líder abipón se moviera como pez en el agua en la turbulencia de los enfrentamientos bélicos. Si por un lado, prestigio guerrero no era lo que le faltaba, por el otro, no podía correr el riesgo de debilitar su autoridad descansando en la fama de hazañas pasadas. Entonces, podría ser que el mantenimiento de la guerra contra los "enemigos de los españoles" -aunque fueran abipones- tenía valor en sí mismo en tanto le garantizaba un campo tradicionalmente propicio para la demostración de sus virtudes y el mantenimiento y fortalecimiento de su autoridad entre los grupos indígenas. Al mismo tiempo la "lealtad con la sociedad colonial" le permitió cultivar "amistades ventajosas" y acceder a un nuevo abanico de posibilidades políticas y económicas mediante las cuales, en última instancia, retroalimentaba su propio prestigio.

\section{Un mundo de nuevas posibilidades: estrategias económicas y el acceso a nuevos recursos}

Ychoalay, desde los primeros contactos con los santafesinos participó activamente de las nuevas posibilidades del circuito económico ofreciéndose como mano de obra en estancias y viñedos. Mediante estas actividades, seguramente estableció un contacto más estrecho con bienes y productos de origen europeo, conoció nuevos mercados y se interiorizó en los términos de los intercambios. Al regresar con los abipones, momento en que inició su carrera por el liderazgo, llevó consigo estos nuevos conocimientos que le permitieron moverse acertadamente en las empresas emprendidas; recordemos la gran capacidad de Ychoalay para conseguir grandes botines a través de las incursiones en estancias y ciudades coloniales, que habrían mantenido su prestigio en alza y un gran séquito de seguidores. Lamentablemente no contamos con muchos documentos que nos permitan acceder a información específica sobre el flujo de los intercambios para este período y, a pesar de que contamos con muchos indicios de la existencia de un amplio comercio entre indígenas y colonos, no nos es posible seguir la trayectoria de Ychoalay desde esta perspectiva.

Hemos señalado que las reducciones fueron espacios de circulación de bienes a través de donativos y regalos. San Jerónimo, sobre todo, surgió por el compromiso mutuo, la amistad y las redes de intercambio entre ciertos caciques abipones y los vecinos de Santa Fe, tratativas de las cuales Ychoalay formó parte desde un principio. Pero si bien Ychoalay debe haber participado de los círculos distributivos de regalos y ganados, sus estrategias económicas parecen haber pasado por el aprovechamiento de otro conjunto de posibilidades que se crearon en torno al espacio reduccional y las relaciones con el sector colonial. Dobrizhoffer señala que a diferencia de los demás, 
Ychoalay nunca les pedía nada a los misioneros y se preocupaba por proteger los bienes de la misión e, incluso, rechazaba ciertas retribuciones como la ración de yerba que entregaban los jesuitas a cambio de trabajo:

Con toda prudencia temía habituarse al uso de esta costosa bebida y verse obligado alguna vez a conseguirla con gastos o con ruegos. Todos los días dábamos una porción de esta yerba a los abipones ocupados con el arado o el hacha. Ychoalay se preocupó que no la usaran [...] [sosteniendo que] 'la costumbre se les hará naturaleza y su bebida les impondrá una durísima obligación. Los padres os proveerán de yerba mientras aréis; después que dejéis de arar os la negarán, y deberéis comprarla a mayor precio. Absteneos, pues, mientras la tenéis, y nunca sentiréis la molestia de carecer de ella (Dobrizhoffer [1784] 1969: 150).

Esta cita que nos muestra un Ychoalay excesivamente elocuente nos obliga a considerar la gran admiración que este sujeto despertaba en Dobrizhoffer; pero incluso tratándose de pura subjetividad del jesuita, no podemos pasar por alto que la creación de nuevas necesidades en vistas de una mayor dependencia colonial, no era un mecanismo desconocido ni se imponía de manera directa y por ciega fascinación. Otra observación que merece atención es la relación que aquí se establece entre trabajo y distribución de bienes, característica propia de la relación entre un cacique y sus seguidores. Cuando un líder indígena movilizaba la ayuda de los suyos, ya fuera en la guerra, en las actividades de caza o en la construcción de sus viviendas, el trabajo prestado debía retribuirse mediante el justo reparto del botín, de la carne o la preparación de grandes festines en donde no debían faltar abundantes brindis de chicha, bebida preparada por sus mujeres con los frutos de la algarroba (Susnik 1981, Saeger 2000). Así, resulta significativo que Ychoalay -líder indígena de San Jerónimo y por lo tanto distribuidor- no haya aceptado posicionarse en el rol de receptor que, simbólicamente, indicaba que la autoridad pasaba en ese momento por otros carriles ${ }^{14}$. Bajo esta misma óptica deberíamos interpretar que "Ychoalay, distinto a los suyos en todas las otras cosas, se prodigaba por propia voluntad en todo tipo de trabajos. Muy enemigo de la adulación y de la especulación en provecho propio, se mostró voluntarioso para con los padres en cualquier trabajo" (Dobrizhoffer [1784] 1969: 147). Contrariamente a la valoración de Dobrizhoffer, creemos que estas actitudes deberían enmarcarse precisamente en la lógica opuesta de la autopromoción, "de la adulación y de la especulación en provecho propio", quizá no hacia los jesuitas, pero sí hacia sus propios seguidores. Las ventajas rápidas y seguras que garantizaba la

\footnotetext{
${ }^{14}$ Desde una perspectiva semejante, Saeger (2000) ha señalado que los grupos abipones habrían visto al cura como una especie de líder, justamente por su función en la distribución de bienes. Este autor plantea que parte del fracaso de la empresa reduccional habría estado relacionada con la incapacidad de los jesuitas de captar esta relación y posición de autoridad, entendida en términos nativos, en la que los indígenas los habrían posicionado.
} 
vida reduccional a través de entregas y regalos, probablemente no eran compatibles con el fortalecimiento de su autoridad. Como veremos, Ychoalay halló la forma de reunir en torno suyo un gran capital económico mediante otro tipo de actividades.

En primer lugar, debemos señalar que, paralelamente a los intercambios comerciales, había otras transacciones entre los grupos indígenas reducidos y la sociedad colonial vehiculizadas en función de las "paces" y la adquisición de mutuos compromisos. Este tipo de circulación adoptaba una forma más cercana a los mecanismos del "don" -o la circulación de "gentilezas" en ambos sentidos de la relación- que al juego del comercio. Cuando las paces fueron acordadas, Ychoalay "devolvió a las ciudades de los españoles más de mil caballos que durante muchos años había robado con sus piratas y los restituyó a sus dueños [...]. No niego que los españoles como son agradecidos por naturaleza con los que le hacen algún servicio, y generosos, recompensaron con ganados a su amigo Ychoalay" (Dobrizhoffer [1784] 1969: 138).

Estos donativos que se hacían de manera aparentemente desinteresada fortalecían los compromisos adquiridos e iniciaban una cadena de "favores", dones y contra-dones que se prolongaban por largos períodos. En términos de Mauss (1971), el don crea la deuda que obliga y constriñe a su devolución. En varias ocasiones, Ychoalay fue retribuido personalmente por el gobernador o el misionero por los servicios prestados o los trabajos realizados. Juan Victorino Martínez de Tineo, Gobernador Tucumán, "envió unas cartas honoríficas a Ychoalay en las que encomió su fe integérrima en los Padres, le dio insistentemente las gracias y remuneró la tarea cumplida de transportar las cosas de la misión desierta, con un paño rojo que bastaría para vestir a cualquier español noble" (Dobrizhoffer [1784] 1969: 144).

Los donativos poseían fuertes connotaciones simbólicas -reforzamiento de la amistad, reconocimiento colonial de su valentía, renovación de los compromisos mutuos, etc.-y eran también el punto de partida para la participación mercantil. Ychoalay supo manipular estas oportunidades sacando rédito de las relaciones interpersonales que había cultivado sin poner en peligro su propio prestigio. Así, por ejemplo, nunca usó el paño entregado por Tineo porque con esa vestimenta resaltaría entre los demás, actitud poco tolerada para un líder que debía mostrarse como un igual entre los suyos, a la vez que corría el riesgo de que alguno de sus seguidores se lo solicitase -según la costumbre- y perder así el beneficio conseguido (Lucaioli 2005). Inteligentemente, "con este paño adquirió las ovejas que le producirían la lana para hacerse según su deseo las ropas que usan los abipones, tejidas como un tapiz turco" (Dobrizhoffer [1784] 1969: 144). De esta manera, Ychoalay logró adaptar los beneficios que le trajo aparejada su posición de amistad con el sector colonial a los valores tolerados para fundamentar su liderazgo entre los abipones.

Con este ejemplo, entramos ya en el plano de los intercambios comerciales, en donde el ganado adquirió notable preponderancia, circulando en grandes cantidades y en ambas direcciones (Susnik 1981, Saeger 2000, Santamaría 2007). Las referencias a 
este tipo de transacción se vuelven más asiduas en las misiones y, generalmente, aluden a la consecución indígena de manadas en otras ciudades o reducciones y su posterior inserción en las ciudades amigas. Ychoalay, que aparentemente mantuvo relaciones de "amistad generalizada" para con la colonia, no por ello dejó de participar de estos negocios. Utilizando los mismos circuitos interétnicos con los que se desenvolvía en la guerra -"amigo de los españoles" / "enemigo de los enemigos a los españoles"sustraía los ganados de los grupos indígenas "rebeldes" en nombre de venganzas o resarcimientos por insultos cometidos y los insertaba en la esfera de los intercambios:

\begin{abstract}
Ychoalay, acompañado por un grupo de sus jinetes, atacó una noche de luna llena al caserío [de la reducción de Timbó] y sin que nadie se le opusiera se llevó cuantos caballos encontró allí. Excitados por estos asaltos nocturnos, se resarcían totalmente de la pérdida de sus caballos con nuevas rapiñas. Y algunos españoles no se avergonzaban de comprar estos caballos producto de robos, y con este comercio los indios se animaban más ardientemente a proseguir con sus hurtos (Dobrizhoffer [1784] 1969: 269-270).
\end{abstract}

Por otra parte, las reducciones brindaban una serie de ventajas para las actividades ganaderas, con infraestructura básica de corrales y campos de pastoreo aptos para la cría y reproducción (Lucaioli y Nesis 2007). Ychoalay, que siempre colaboró con los misioneros en el cultivo de los huertos y el cuidado del ganado comunal destinado al consumo de la población, muy pronto comenzó a aplicar estos conocimientos en su propio terreno y para provecho propio. De esta manera, ya para la década de 1750 , "tenía un predio junto al arroyo Malabrigo, rico en numerosos ganados y rebaños de ovejas" (Dobrizhoffer [1784] 1969: 183). El número de reses que Ychoalay habría logrado reunir hacia el final del período jesuítico se ilustra en un episodio en donde se menciona que "tres abipones de los nuestros [del Timbó] que traían unos dos mil caballos robados de los predios de Ychoalay, para vengar la muerte de algunos de los nuestros a manos de él [...]. Ytioketalín, viendo tan grande botín de caballos, no dudaba de que Ychoalay fuera el dueño de los animales" (Dobrizhoffer [1784] 1969: 298).

No cabe duda que Ychoalay supo aprovechar las ventajas que al respecto le brindaba el entorno reduccional e, incluso cuando tras la expulsión muchos abipones abandonaron las misiones, este caudillo permaneció en San Jerónimo al cuidado de sus predios en donde tenía "más de mil vacas mansas de rodeo y más de cien caballos mansos y una gran porción de yeguas. Siembra sus chacras de maíz, zapallo y otras miniestras; y con esto se mantienen" (Castro 16/10/1766).

\title{
El liderazgo político: autoridad indígena y amistades ventajosas
}

El prestigio de Ychoalay comenzó a florecer con sus exitosos ataques a las ciudades coloniales. Durante aquel período, la carrera de su liderazgo se inscribió dentro 
de los canales tradicionales de ascenso y promoción política. Sin embargo, cuando se posicionó como "amigo" de los hispanocriollos y reorientó los enfrentamientos armados contra los sectores "desertores" de su propio grupo étnico, su autoridad entendida en los términos tradicionales comenzó a resquebrajarse y "A veces, cuando invitaba a sus compañeros a defender la fundación contra los enemigos, le volvían la espalda excusándose en la falta de caballos aptos" (Dobrizhoffer [1784] 1969: 138).

Frente a esta realidad, Ychoalay halló la manera de fortalecer aquel consenso debilitado apelando a las nuevas coordenadas delineadas por las relaciones interétnicas fronterizas. Debemos indagar, entonces, cuáles fueron las transformaciones y adaptaciones que comenzaron a operarse en torno al liderazgo que le permitieron coordinar la nueva coyuntura sociopolítica y económica con las formas tradicionalmente reconocidas de ejercer la autoridad. En este punto, creemos que el contexto bélico que acompañó el siglo XVIII jugó un importante papel para permitir dicha articulación. Así, las guerras sostenidas por Ychoalay ya sea contra el frente colonizador -durante las primeras décadas-, contra los grupos abipones "rebeldes" -durante el período jesuíticoo contra otros grupos indígenas, principalmente mocovíes y tobas -durante las décadas de 1770 y 1780 - crearon campos propicios para el desarrollo de su liderazgo en los términos tradicionales de demostración de capacidad de mando y astucia bélica. A su vez, su carisma y generosidad sumados a las nuevas ventajas económicas sentaron las bases para mantener el poder de convocatoria que necesitaba, ya que, tal como se esperaba

daba a cualquiera que saliéndole al paso se los pidiera sus vestidos de lana teñidos con elegantes colores que su mujer recién le había tejido. Usó esta liberalidad con todos los que empleaba para arar sus campos o esquilar sus ovejas. Por eso cada año acudía una multitud de ambos sexos para ayudar a Ychoalay. La paga de los operarios se limitaba solo al sustento y a las gratuitas larguezas anuales. Alimentaba con liberalidad a los que trabajaban para él con lo que su economía se veía perjudicada (Dobrizhoffer [1784] 1969: 149).

Así, si por alguna razón -que no concuerda con lo que ya hemos analizado"su economía se veía perjudicada", su carrera política se fortalecía en este accionar y adquiría mayor consistencia y estabilidad. Esta cita también es sugerente en relación con el capital económico que Ychoalay habría logrado reunir. Nos referimos a la capacidad de movilizar mano de obra para su propio provecho -aparentemente por fuera del círculo de parientes directos- utilizando y adaptando los tradicionales mecanismos de reciprocidad que garantizaban la ayuda y cooperación del grupo familiar a cambio de alimento para las nuevas actividades económicas. Por lo tanto, nos inclinamos a pensar que los términos utilizados en este pasaje relativos al "empleo y paga de los operarios" remiten exclusivamente al discurso culturalmente orientado de Dobrizhoffer 
y que, desde el punto de vista indígena, este tipo de actividad debería interpretarse dentro de la óptica de la reciprocidad. Por otra parte, a lo largo de todo el siglo XVIII y hasta bien entrado el XIX, no encontramos a los grupos del Chaco insertos en el tipo de relación capitalista que supone un verdadero mercado del trabajo indígena ${ }^{15}$. Se trataría, entonces, de una adaptación original de las reglas del juego tradicional a las nuevas actividades propuestas por el contexto económico. A su vez, creemos que esta transformación no debe interpretarse como incapacidad de los grupos indígenas de escapar a sus "constreñimientos culturales", sino por el contrario, como muestra de la plasticidad cultural y la acción estratégica de adaptarse a los cambios sin perder convocatoria y respaldo.

Por otra parte, el manejo del idioma español le permitió a Ychoalay mantener una estrecha relación y comunicación con el sector colonial posicionándose en numerosas ocasiones como mediador diplomático entre indígenas e hispanocriollos. El uso de la palabra fue otro de los aspectos que Ychoalay supo explotar y no sólo dentro de su propio grupo, sino también en el contexto interétnico, cuestionando incluso el accionar de las altas esferas burocráticas de los engranajes coloniales. Un curioso ejemplo nos llega en ocasión de la noticia de la inminente expulsión de los jesuitas, motivo por el cual Ychoalay viajó personalmente a Buenos Aires para entrevistarse con el Gobernador y defender sus intereses -que, como hemos visto, en gran medida se sustentaban en el funcionamiento de la reducción de San Jerónimo-:

Llegado a la ciudad se encaminó hacia el palacio del Sr Bucareli, metiéndose por medio de las guardias de la Fortaleza, donde está el Palacio, con tanto despejo y gravedad, como lo pudiera hacer un palaciego, y puesto en presencia del Sr Bucareli, sin perder el tiempo en ceremonias le dijo: Yo vengo a preguntarte, ¿por qué nos han sacado de los pueblos a los padres? Sorprendiese su Excelencia con esta pregunta, y como sabía bien quién era Benavides, se guardó muy bien de exasperarle con alguna respuesta descompasada, y así procuró satisfacerle con buen modo diciendo que el Rey lo había mandado. Más como el indio le replicase que no era posible que el Rey lo hubiese mandado sino estando muy engañado, dijo el Sr Bucareli, que eso no le tocaba a él examinarlo. Es así, contestó entonces el Indio; pero a ti te toca informar luego y en por menor a Su Majestad de la falta que hacen los padres, y sabiendo esto el Rey no mandarán que salgan. Sobrecogido el Sr Bucareli de esta razón tan fuerte, no tuvo qué responder (Olcina citado por Furlong 1938: 172).

\footnotetext{
${ }^{15}$ Las dinámicas de incorporación de los grupos indígenas del Chaco al mercado capitalista y la explotación laboral a partir del siglo XIX han sido abordadas por Trinchero et al. (1992) y Trinchero (2000 y 2007).
} 
Dobrizhoffer ([1784] 1969: 169) señala otras ocasiones en las cuales Ychoalay pregonaba discursos en la reducción, primero en su lengua y luego en español, para que entendieran tanto los abipones como los misioneros lo que se estaba acordando. Así, encarnaba en persona aquella cualidad que Bechis ([1989] 2008) destacó de los caciques indígenas, Ychoalay era un verdadero "procesador de información". En cuanto a la relación con sus seguidores, si bien la oratoria y la elocuencia eran elementos claves para conseguir apoyo, siempre debieron orientarse para la consecución del consenso grupal que limitaba el ejercicio del liderazgo y la capacidad de representación. Si bien Dobrizhoffer ([1784] 1969: 139) sostiene que Ychoalay, "aunque no tuviese la suma autoridad sobre los demás habitantes, sin embargo todos los asuntos eran moderados en la fundación por su consejo y su autoridad", los habitantes de San Jerónimo podían hacer oídos sordos a estos consejos y seguir sus propias iniciativas ${ }^{16}$.

La aparente identificación de Ychoalay con los objetivos hispanocriollos y, más aún, la dramatización de esa identificación orientada hacia la colonia -entendiendo sus manifestaciones como una performance en el sentido que le da Turner (1974)- le habría abierto las puertas al establecimiento de relaciones interpersonales altamente ventajosas con misioneros, gobernadores, capitanes de milicias y comerciantes. Si bien en sí mismas estas relaciones no contribuyeron a afianzar su autoridad, trajeron aparejadas una serie de beneficios -como la adquisición de nuevos productos y la posibilidad de contar ocasionalmente con respaldo militar- que luego, estratégicamente, podían incorporarse a los circuitos tradicionales y fortalecer su liderazgo mediante el reparto de bienes materiales o la protección y seguridad de la reducción. Así, si desde el sector colonial Ychoalay puede haber representado un "aliado político" en tanto "enemigo de sus enemigos" (Weber 1998), desde el punto de vista indígena esta relación debería leerse en otros términos. Esa correspondencia es apenas aparente y esconde otros motivos que no se relacionan con un el sometimiento ni la manipulación por parte de algún funcionario colonial. La representación de esta relación desde la perspectiva de Ychoalay no devolvería una imagen homóloga de aquella otra, los hispanocriollos no era para él simplemente los "enemigos de sus enemigos" sino, por sobre todo, "sus amigos", amistades labradas con cuidado, políticamente estratégicas y orientadas a la consecución de prestigio en su propia sociedad.

De esta manera, aquel "Joseph Benavides indio ordinario sin más requisito, que ser amigo del lugarteniente de Vuestra Señoría de la ciudad de Santa Fe" (Patrón 24/3/1750) habría dejado de ser "ordinario" justamente porque supo cultivar aquella amistad al servicio de su propia promoción. La amistad de Ychoalay con el Teniente de Gobernador Francisco Antonio de Vera Mujica, finalmente se habría afianzado

\footnotetext{
${ }^{16}$ Por ejemplo, en cierta ocasión en que sus seguidores habían decidido abandonarlo, Ychoalay se dirigió a los misioneros con estas palabras: “ ¡Oh vosotros, padres, $[. .$.$] nuestro pueblo todo él está meditando$ abandonar la reducción y la amistad de los españoles; y no tengo qué oponerles [...]. No podemos decir que los españoles son nuestros enemigos, pero tampoco nuestros amigos si no creyéramos que sus promesas de amistad se limitan sólo a palabras. Y es por esto que mis compañeros han cambiado súbitamente su ánimo, han pensado en retirarse. Yo en verdad, me veo impotente para defenderos" (Dobrizhoffer [1784] 1969: 168).
} 
mediante actos ritualizados que sellaron aquellos vínculos políticos. Cuando Ychoalay finalmente decidió bautizarse, a diferencia de los demás indígenas, lo hizo en la iglesia de la ciudad de Santa Fe y “el mismo Teniente de Gobernador apadrinó al ilustre neófito acompañándolo con adecuados regalos y una mesa espléndida" (Dobrizhoffer [1784] 1969: 142). Esta relación, sobre todo, habría sido promovida desde el sector colonial y apoyada por funcionarios tanto civiles como gubernamentales:

el Señor Teniente de Gobernador y Justicia Mayor de esta Ciudad muchas veces se había ofrecido para ser Padrino de Bautismo a Ychoalai, para más moverlo a que se bautizase, y para hacer más solemne tan difícil y deseada conversión, pareció conveniente se hiciese su Bautismo en esta Ciudad. Vino pues dicho Padre Leman con su Catecúmeno, y se Bautizó Ychoalai después de Pascuas de Resurrección, siendo su Padrino dicho Señor Teniente y concurriendo a la solemnidad del Bautismo el Cabildo de la Ciudad, Religiosos de todas las órdenes, y lo más granado y noble de todos gremios (Anua del Colegio de Santa Fe 1757).

Así, mientras Ychoalay cruzaba el umbral que lo incluía entre "los hijos de Dios", también derribaba otras fronteras simbólicas entre el mundo indígena y el colonial, ampliando la senda que unía al Chaco con su reducción y la ciudad de Santa Fe. Paralelamente, la entrega de bienes de prestigio y simbólicos tales como el nombramiento de Ychoalay como "Capitán Cacique Corregidor" del pueblo de San Jerónimo (de la Riva Herrera 4/1/1776), el apelativo "Don Joseph Benavides" (Actas del Cabildo de Santa Fe 22/4/1776), el padrinazgo del Teniente de Gobernador de Santa Fe en su bautismo y la entrega de ropas especiales y objetos de valor (Dobrizhoffer [1784] 1969: 149) eran otros tantos elementos de aquella performance políticosimbólica orientada a mostrar la solidaridad con el apoyo español. Sin embargo, hacia adentro del grupo, aquellos mismos elementos fueron resignificados y cargados con nuevos sentidos ajenos a la esfera del sector colonial. Por lo tanto, desde el punto de vista indígena estas entregas no parecen haber tenido carácter performativo -en el sentido de crear nuevos roles por su mera adquisición- ni sustentado en sí mismas nuevos tipos de poder entre los grupos abipones.

\section{Consideraciones finales}

La trayectoria de Ychoalay nos guió en el análisis de estas adaptaciones, en donde lo vimos interactuar como un verdadero estratega al mover coordinadamente los hilos de sus propios intereses y los de su grupo, logrando articular las formas tradicionales de ejercer su autoridad con las nuevas posibilidades que se les iban presentando. Las transformaciones operadas en este contexto se vieron igualmente contenidas por los viejos paradigmas que mantenían en vigencia la preponderancia 
del consenso grupal, el apoyo fluctuante de los seguidores, las limitaciones para la acumulación de la riqueza y la imposibilidad de imponer un poder coercitivo. Dichos elementos no habrían permitido sentar las bases para el tipo de poder político centralizado ni la infraestructura económica que supone el surgimiento de jefaturas, en los términos descriptos por Carneiro (1981) ${ }^{17}$. De esta manera, el análisis que aquí hemos presentado estaría discutiendo con aquella postura que señala que a lo largo del siglo XVIII, la asiduidad de los contactos entre agentes hispanocriollos y grupos indígenas habría generado la disminución de los conflictos bélicos, por un lado y, por otro, el surgimiento de un nuevo tipo de jefatura avalada por la colonia (Vitar 2003, Paz 2005). Dichos autores sostienen que tales "jefaturas intervenidas" se habrían sustentado en el mantenimiento de una "alianza firme" con los españoles fundada en una mayor dependencia política y económica de la sociedad indígena respecto del respaldo de las autoridades coloniales y los bienes que estos le proveían para su sustento (Vitar 2003: 417).

Desde nuestro punto de vista, el proceso de interacción económica -y también política - que habría tenido lugar durante el siglo XVIII no muestra una tendencia unidireccional hacia una mayor centralización del poder político ${ }^{18}$ ni supone a una sociedad indígena dependiente de las esferas coloniales. En este sentido, creemos que sería más acertado hablar, en todo caso, de una mayor "interdependencia" económica, pero que, fundamentalmente, ambos sectores mantuvieron independencia política por fuera del espacio generado por su interacción. Por último, creemos que estas adaptaciones estratégicas tampoco pueden interpretarse desde aquella perspectiva que sostiene que, en los contextos reduccionales, las entregas de regalos -entra otras cosashabrían socavado las bases de la autoridad abipona y resquebrajado los principios políticos (Djenderedjian 2004). Como hemos visto, al menos para el período jesuítico, los caciques abipones supieron adaptarse estratégicamente y reinventarse políticamente jugando con las múltiples posibilidades desplegadas en la interacción con la colonia. En los márgenes de la colonia, los grupos abipones fueron capaces de escapar, por largo tiempo, a la dominación económica y social y a la subordinación política, no por caer presos de su propia tradición sino porque fueron capaces de transformar sus instituciones sociales, políticas y económicas.

\footnotetext{
${ }^{17}$ Las jefaturas implicarían la centralización del poder político en manos de unos pocos líderes, quienes ocuparían cargos preexistentes. Asimismo, el ejercicio del poder se sustenta en la capacidad de los jefes de ejercer su dominio a partir de la imposición de sanciones negativas.

${ }^{18}$ Algunos autores han interpretado el proceso histórico de los indígenas "chaqueños" a partir de una serie de cambios comunes caracterizada principalmente por un supuesto fortalecimiento político que habría dado lugar al surgimiento de las denominadas "jefaturas" o "cacicazgos" (Cordeu y Siffreddi 1971, Saeger 2000, Paz 2003 y 2005 y Vitar 2003). Esta postura se encuentra estrechamente ligada al presupuesto evolucionista que considera a las "bandas", las "jefaturas" y el "estado" como etapas escalonadas de la organización sociopolítica en un grado de creciente complejidad, invisibilizando la variabilidad de estrategias y respuestas elaboradas por las distintas agrupaciones en contextos y situaciones particulares (Nesis y Lucaioli 2006).
} 
Las reducciones oficiaron como "portales" 19 que favorecieron la conexión y confluencia del mundo hispanocriollo con el Chaco no colonizado; del "estado colonial" con el "mundo nativo". Estos espacios liminales fueron para los grupos abipones contextos novedosos que brindaban la posibilidad de poner entre paréntesis ciertos dictámenes culturales predisponiendo el ensayo creativo y la adaptación estratégica frente a las nuevas coordenadas delineadas por las relaciones interétnicas. En este sentido, consideramos que las reducciones generaron contextos propicios de "aculturación antagónica" (Bechis 2006), permitiendo la mezcla y la adaptación original de un nuevo abanico de posibilidades y relaciones orientadas al mantenimiento de la autonomía indígena.

\section{Fuentes de archivo}

Abreviaturas:

AGI - Archivo General de Indias (Sevilla, España)

AGN - Archivo General de la Nación (Buenos Aires, Argentina)

APSF - Archivo Provincial de Santa Fe (Santa Fe, Argentina)

BNRJ - Biblioteca Nacional de Río de Janeiro (Río de Janeiro, Brasil)

Actas del Cabildo de Santa Fe

8/6/1748. Actas de la sesión del Cabildo de Santa Fe celebrada el 8 de junio de 1748. APSF, Actas de Cabildo XII.

8/11/1748. Actas de la sesión del Cabildo de Santa Fe celebrada el 8 de noviembre de 1748. APSF, Actas de Cabildo XII.

10/6/1754. Actas de la sesión del Cabildo de Santa Fe celebrada el 10 de junio de 1754. APSF, Actas de Cabildo XII.

21/11/1775. Actas de la sesión del Cabildo de Santa Fe celebrada el 21 de noviembre de 1775. APSF, Actas de Cabildo XIV.

22/4/1776. Actas de la sesión del Cabildo de Santa Fe celebrada el 22 de abril de 1776. APSF, Actas de Cabildo XIV.

Anua del Colegio de Santa Fe

1757. Anua del Colegio de Santa Fe. Santa Fe, 1757. BNRJ - 508 (33).

Breve relación

s/f. Breve relación de la fundación de la Concepción [aunque no lleva firma sabemos que fue escrita por Francisco de la Barreda]. BNRJ, MS 508 (33).

Brigniel, José

6/4/1749. Carta de José Brigniel a José de la Barreda. San Jerónimo del Rey, 6 de abril de 1749. BNRJ, MS 508 (33).

\footnotetext{
${ }^{19}$ Tomamos prestada la expresión de Taussig (1990) y el sentido que el autor le otorga en tanto conectores simbólicos entre diferentes sistemas de representación.
} 
22/1/1752. Carta de José Brigniel al Alcalde (¿?). San Jerónimo del Rey, 22 de enero de 1752. AGN IX, 4-1-2.

Castro, Manuel de

16/10/1766. Informe presentado por el Coronel de Milicias Don Manuel de Castro sobre la situación de las reducciones de San Jerónimo de Santa Fe y Santiago de indios Abipones. Lima, 16 de octubre de 1766. AGI, Buenos Aires 244.

3/12/1766. Informe presentado por el Coronel de Milicias Don Manuel de Castro sobre la situación de las reducciones de San Jerónimo de Santa Fe y Santiago de indios Abipones. Lima, 3 de diciembre de 1766. AGI, Buenos Aires 244.

Churraca, Juan Tomás

23/12/1774. Carta de Juan Tomás Churraca a (¿?). San Pedro, 23 de diciembre de 1774. AGN IX, Santa Fe 4-1-5.

de la Riva Herrera, Juan Francisco

21/4/1776. Carta de Juan Francisco de la Riva Herrera a Juan José de Vértiz. Cañada Honda, 21 de abril de 1776. AGN IX, Santa Fe 4-1-5.

Klain, José

11/11/1758. Carta de José Klain a Pedro de Cevallos. Corrientes, 11 de noviembre de 1758. AGN IX, Corrientes 3-3-6.

Patrón, Nicolás

24/3/1750. Carta de Nicolás Patrón a José de Andonaegui. Corrientes, 24 de marzo de 1750. AGN IX, Corrientes 3-3-6.

8/9/1758. Carta de Nicolás Patrón a Pedro de Cevallos. Corrientes, 8 de septiembre de 1758 . AGN IX, Corrientes 3-3-6.

Paucke, Florián

1764. Carta de Florián Paucke a Nicolás Contucci. San Javier, 1764. BNRJ, 508 (33).

Sánchez, José

16/1/1751. Carta de José Sánchez a Francisco de la Barreda. Concepción, 16 de enero de 1751. BNRJ, MS 508 (33).

Urízar, Pedro Florentino

30/6/1754. Carta de Pedro Florentino de Urízar a José de Andonaegui. Santa Fe, 30 de junio de 1754. AGN IX, Santa Fe 4-1-2

\section{Referencias Bibliográficas}

Bechis, Martha. 2006. 'La 'organización nacional' y las tribus pampeanas en argentina durante el siglo XIX”. Tefros 4 (2).

Bechis, Martha. 1989] 2008. "Los lideratos políticos en el área araucano-pampeana en el siglo XIX. ¿Autoridad o poder?”. En Bechis, Martha. Piezas de etnohistoria del sur 
Folia Histórica del Nordeste, $\mathbf{N}^{\circ} 19$ (Resistencia, 2011) IIGHI, IH - CONICET, UNNE

sudamericano: 263-296. Madrid, CSIC.

Boccara, Guillaume. 2002. "“Mestizaje salvaje”, trabajo y resistencia en la frontera hispanomapuche". En França Paiva, E. y C.M. Junho Anastasia (org.) O Trabalho Mestiço: 265-279. Sao Pablo.

Boccara, Guillaume. 2005. "Génesis y estructura de los complejos fronterizos euro-indígenas. Repensando los márgenes americanos a partir (y más allá) de la obra de Nathan Wachtel”. Memoria Americana 13: 21-52.

Braunstein, José. 1983. Algunos rasgos de la organización social de los Indígenas del Gran Chaco. Buenos Aires, Facultad de Filosofía y Letras.

Braunstein, José. 2008. “"Muchos caciques y pocos indios” Conceptos y categorías del liderazgo indígenas chaqueño”. En Braunstein, J. y N. Meichtry (eds.), Liderazgo, representatividad y control social en el Gran Chaco: 5-32. Corrientes, Editorial Universitaria de la Universidad Nacional del Nordeste.

Carneiro, Robert. 1981. "La jefatura: precursora del estado". En Grant D. Jones y Robert R. Kautz, The transition to statehood in the bew world (37-79). Cambridge University Press.

Cervera, Manuel. 1907. Historia de la ciudad y provincia de Santa Fe 1573-1853. Santa Fe, R. Ibáñez.

Cervera, Federico. 1969. "Añapiré. Un lugar histórico de Santa Fe". Revista de la Junta Provincial de Estudios Históricos de Santa Fe XLI: 12-34. Santa Fe.

Charlevoix, Pedro F. X. de

[1779] 1916. Historia del Paraguay. Tomo VI. Madrid, Librería General de Victoriano Suárez.

Clastres, Pierre. 1977. "La desgracia del guerrero". En: Investigaciones en antropología política: 217-256. México, Gedisa.

Cordeu, Edgardo y Alejandra Siffredi. 1971. De la Algarroba al Algodón. Movimientos milenaristas del Chaco Argentino. Buenos Aires, Juárez.

Djenderedjian, Julio. 2004. "Del saqueo corsario al regalo administrado. Circulación de bienes y ejercicio de la autoridad entre los abipones del Chaco oriental a lo largo del siglo XVIII". Folia Histórica del Nordeste 15: 175-195. Resistencia, Instituto de Investigaciones Geohistóricas, CONICET e Instituto de Historia, Facultad de Humanidades, UNNE.

Dobrizhoffer, Martin. [1784] 1968. Historia de los abipones. Vol. II. Resistencia, Universidad Nacional del Nordeste.

Dobrizhoffer, Martin. [1784] 1969. Historia de los abipones. Vol. III. Resistencia, Universidad Nacional del Nordeste.

Furlong, Guillermo.1938. Entre los abipones del Chaco: según noticias de los misioneros jesuitas Martín Dobrizhoffer, Domingo Muriel, Joaquín Camaño, Jose Jolis, Pedro Juan Andreu, José Cardiel y Vicente Olcina. Buenos Aires, Talleres Gráficos San Pablo.

Fuscaldo, Liliana.1982. La relación de propiedad en el proceso de enfrentamiento social: la propiedad comunal directa a la propiedad privada burguesa. Buenos Aires, CICSO.

Helms, Mary. 1969. "The Purchase Society: Adaptation to economic frontiers". Anthropological Quarterly 42: 325-342.

Lucaioli, Carina. 2005. Los grupos abipones hacia mediados del siglo XVIII. Buenos Aires, Sociedad Argentina de Antropología. 
Lucaioli, Carina . 2010. Relaciones interétnicas y estrategias de interacción: los grupos en abipones en las fronteras del Chaco (siglo XVIII). Tesis de Doctorado, Universidad de Buenos Aires, Facultad de Filosofía y Letras. Inédita.

Lucaioli, Carina y Florencia Nesis. 2007. "El ganado vacuno de los grupos abipones y mocoví en el marco de las reducciones jesuíticas, 1743-1767”. Andes 18: 129-152.

Mauss, Marcel. 1971. Sociología y Antropología. Madrid: Tecnos.

Nacuzzi, Lidia R. 1998. Identidades impuestas. Buenos Aires, Sociedad Argentina de Antropología.

2009. "Parte I. Los cacicazgos del siglo XVIII en ámbitos de frontera de Pampa-Patagonia y el Chaco". En prensa.

Nacuzzi, Lidia R. y Carina P. Lucaioli. 2008. “““y sobre las armas se concertaron las paces”: explorando las rutinas de los acuerdos diplomáticos coloniales”. CUSHO - Cultura, Hombre, Sociedad 15 (2): 61-74. Temuco, Universidad Católica de Temuco.

Nesis, Florencia y Carina Lucaioli. 2007. "El liderazgo político en un espacio de contacto: el Chaco austral en el siglo XVIII". Actas de las IV Jornadas Nacionales Espacio, Memoria e Identidad. Rosario: Centros de Estudios, Espacio, Memoria e Identidad, Universidad Nacional de Rosario y Universidad Nacional de Rosario Editora.

Muriel, Domingo. 1919. Historia del Paraguay de 1747 a 1767. Madrid. Librería General de Victoriano Suárez. Colección de libros y documentos referentes a la historia de América. Tomo XIX.

Palermo, Miguel Ángel. 1986. "Reflexiones sobre el llamado "complejo ecuestre" en la Argentina”. Runa XVI: 157-178. Buenos Aires, Instituto de Ciencias Antropológicas de la UBA.

Paucke, Florian. 1944. Hacia Allá y para Acá. Una estadía entre los indios Mocobies, 17491767. Vol. III, Tucumán, Universidad Nacional.

Paz, Carlos. 2003. ““CCómo es su costumbre hacer casi cada año...”. Algunas consideraciones sobre las actividades económicas de los pueblos del Gran Chaco argentino". Siglo XVIII. En Mandrini, R. y C. Paz (comps.); Las fronteras hispanocriollas del mundo indígena latinoamericano en los siglos XVI-XIX: 377-405. Tandil, CEHiR/UNS/Instituto de Estudios Histórico Sociales.

Paz, Carlos. 2005. "El nudo gordiano de las políticas indígenas de los grupos chaqueños. Misiones, misioneros y guerras en la génesis de una sociedad de jefatura, segunda mitad del siglo XVIII". Revista Historia UNISINOS 9 (1): 35-48. São Leopoldo, Universidade do Vale do Rio dos Sinos.

Saeger, James. 2000. The Chaco Mission Frontier. The Guaycuruan Experience. Tucson Arizona, The University of Arizona Press.

Santamaría, Daniel. 2000. "La sociedad indígena". Nueva historia de la Nación Argentina II. Buenos Aires, Editorial Planeta.

Santamaría, Daniel . 2007. Chaco Gualamba. Del monte salvaje al desierto ilustrado, Jujuy, Cuadernos del Duende.

Schindler, Helmut. 1985. "Equestrian and not equestrian indians of the Gran Chaco during de colonial period”. Indiana 10: 451-464. Berlín. 
Susnik, Branislava. 1971. "Dimensiones migratorias y pautas culturales de los pueblos del Gran Chaco y su periferia (enfoque etnológico)". Suplemento Antropológico 7 (1): 85-107.

Susnik, Branislava. 1981. Los aborígenes del Paraguay. Asunción, Museo etnográfico “Andrés Barbero".

Taussig, Michael. 1990. "La magia del Estado: María Lienza y Simón Bolívar en la Venezuela Contemporánea”. En Gutiérrez Manuel, León Portilla Miguel, Gossen Gary, de Alva Klor Jorge (comps). De palabra y obra en el nuevo mundo 2: encuentros interétnicos: 489-518. México, Editorial Siglo XXI.

Turner, Víctor. 1974. "Dramas, Fields and Metaphors. Symbolic Action in Human Society". Cornell University Press.

Vitar, Beatriz. 1995. "Mansos y salvajes. Imágenes chaqueñas en el discurso colonial”. En del Pino, Fermín y Carlos Lázaro (coord.) Visión de los otros y visión de sí mismos: 107-126. Madrid, Consejo Superior de Investigaciones Científicas.

Vitar, Beatriz 1997. Guerra y misiones en la frontera Chaqueña del Tucumán (1700-1767). Madrid, CSIC, Biblioteca de la historia de América.

Vitar, Beatriz 2001a. "Las mujeres chaqueñas en las reducciones fronterizas del Tucumán: entre la tradición y el cambio (siglo XVIII)". Anuario IEHS, 16: 223-244. Tandil, Universidad Nacional del Centro.

Vitar, Beatriz 2001b. "La evangelización del Chaco y el combate jesuítico contra el demonio". Andes 12: 201-221. Salta, CEPIHA.

Vitar, Beatriz 2003. “Algunas notas sobre las figuras de los líderes chaqueños en las postrimerías del siglo XVIII”. En Mandrini, R. y C. Paz (comps.) Las fronteras hispanocriollas del mundo indigena latinoamericano en los siglos XVI-XIX: 407-428. Tandil, CEHiR-UNSInstituto de Estudios Histórico Sociales.

Weber, David. 1998. "Borbones y Bárbaros. Centro y Periferia en al Reformulación de la Política de España hacia los Indígenas no Sometidos”. Anuario IEHS 13: 147-171. Tandil. 